\title{
Decreased Bombesin Peptide Response to Cigarette Smoking in Schizophrenia
}

\author{
Ann Olincy, M.D., M.P.H., Sherry Leonard, Ph.D., David A. Young, Ph.D.,
} Bernadette Sullivan, B.A., and Robert Freedman, M.D.

Schizophrenic patients are extremely heavy tobacco smokers. However, a lower incidence of lung cancer in schizophrenic patients has been observed in comparison to other heavy smokers. Nicotine increases the proliferation of pulmonary neuroendocrine tissue, causing the release of a bombesin-like peptide. Thus, bombesin-like peptide levels in urine may be an indicator of precancerous, cigaretteinduced lung damage. Bombesin-like peptide levels of 10 schizophrenic smokers and 11 schizophrenic nonsmokers were compared to those of nonschizophrenic subjects matched for age and pack-years of smoking. The nonschizophrenic smokers showed the expected increase in urinary bombesin-like peptide levels, as compared to nonschizophrenic nonsmokers. Schizophrenic patients had lower bombesin-like peptide levels independent of smoking effects. The mechanism of the difference in bombesin-like peptide levels between schizophrenic patients and nonschizophrenic subjects is unknown, but one possibility involves alteration in the $\alpha 7$-nicotinic acetylcholine receptor, which mediates the growth of some neuroendocrine cell lines in vitro.

[Neuropsychopharmacology 20:52-59, 1999]

Published by Elsevier Science Inc.
KEY WORDS: Gastrin-releasing peptide; Neuroendocrine cells; Pulmonary inflammation; Nicotinic receptors; Nicotine; Tobacco

Unusually heavy tobacco smoking is associated with schizophrenia. Patients smoke at prevalence rates between 74 and $92 \%$, as compared to 35 to $54 \%$ for all psychiatric patients and 30 to $55 \%$ for the general population (Lohr and Flynn 1992). Among smokers, schizophrenic patients are more likely to smoke more than

From the Department of Psychiatry (AO, SL, BS, RF), Department of Preventive Medicine and Biometrics (DAY), University of Colorado Health Sciences Center, and Denver Veterans Administration Medical Center (SL, RF), Denver, Colorado.

Address correspondence to: Ann Olincy, M.D., M.P.H., Department of Psychiatry, Box C-268-71, University of Colorado Health Sciences Center, 4200 East Ninth Avenue, Denver, CO 80262.

This research was supported by N-A-R-S-A-D, the Veterans Administration Medical Research Service, and USPHS Grants MH4212, MH38321.

Received 9 December 1997; revised 9 March 1998; accepted 21 May 1998. one pack of cigarettes per day and also to choose highnicotine cigarettes (Masterson and O'Shea 1984). Even when schizophrenic patients are matched to other smokers on current cigarette consumption in packs per day, urinary cotinine levels indicate that schizophrenic patients extract at least $50 \%$ more nicotine from tobacco smoke, presumably by inhaling more deeply (Olincy et al. 1997a). Heavy smoking has been related to neuroleptic use (McEvoy et al. 1995); however, smoking is still found to be more intense in schizophrenic patients than in other chronically mentally ill individuals, including those receiving neuroleptic treatment (de Leon et al. 1995).

Paradoxically, schizophrenic patients seem to be partly resistant to the carcinogenic effects of cigarette smoke. Several studies have shown decreased prevalence of lung cancer in these patients, especially when heavy smoking was used as a covariate (Rice 1979; Craig and Lin 1981). However, significance of the lower rates of lung cancer in schizophrenic patients has been questioned (Baldwin 1979; Gulbinat et al. 1992). Be- 
cause schizophrenic patients have elevated mortality from other causes, such as heart disease and suicide, the lower lung cancer mortality may be a secondary effect (Rassidakis et al. 1971). The aim of the present study was to examine the biological response of the lung to cigarette smoking to determine if there are differences between schizophrenic patients and nonschizophrenic subjects.

The lung responds to irritants, such as tobacco smoke, with hyperplasia of pulmonary neuroendocrine cells that are embedded in the airway epithelium (Aguayo et al. 1990). Furthermore, pulmonary cell growth is stimulated by nicotine as is thickening of airways in the lung (Aguayo 1993). This inflammatory response of the neuroendocrine cells includes increased release of a bombesin-like peptide. This peptide is similar to a peptide first isolated from frog skin (Aguayo 1993). Bombesin-like peptide is excreted into the urine, so that urinary bombesin-like peptide levels are an indirect indication of pulmonary neuroendocrine cell proliferation (Aguayo et al. 1992). Bombesin-like peptide receptors and bombesin-like peptide also participate in autocrine-stimulated growth in many small cell lung cancer cell lines (Cuittita et al. 1985). Increased levels of bombesin-like peptide, seen in smokers, may thus promote growth of tumors developing from the carcinogens in cigarette smoke (Hecht and Hoffman 1988; Minna 1993).

This study compares urinary bombesin-like peptide levels in schizophrenic patients and nonschizophrenic subjects. Neuroendocrine cell proliferation, and thus, bombesin-like peptide production occurs after chronic cigarette smoke exposure. Therefore, schizophrenic pa- tients were matched to nonschizophrenic subjects on pack-years (number of packs per day $\times$ number of years of smoking). Control groups of schizophrenic and nonschizophrenic nonsmokers were also examined.

\section{METHODS}

\section{Subjects}

Subjects were recruited from the Denver VAMC and the Colorado Psychiatric Hospital inpatient and outpatient services. Diagnoses of the 10 schizophrenic smokers and 11 schizophrenic nonsmokers were confirmed using DSM-III-R (American Psychiatric Association 1987) criteria and chart review. The examiners were careful to exclude psychoses caused by affective disorders, psychoactive substance abuse, or organic syndromes. Eighteen $(86 \%)$ of the schizophrenic patients were paranoid, chronic subtype, the remaining three $(14 \%)$ were disorganized, chronic subtype. Twenty $(95 \%)$ of the schizophrenic patients were outpatients. Sixteen $(76 \%)$ of the schizophrenic patients were taking traditional neuroleptics, four $(19 \%)$ were taking clozapine, one (5\%) was taking no antipsychotic medication. A detailed smoking history was obtained from each subject, and the cumulative cigarette consumption was expressed in pack-years. Twenty-one comparison subjects, matched to the schizophrenic patients on packyears and age were recruited. They were then screened using the Structured Clinical Interview for DSM-III-R, Nonpatient Edition (SCID-NP; Spitzer et al. 1990) and the Family History Research Diagnostic Criteria (FHRDC; Endicott et al. 1978).

Table 1. Psychiatric Diagnoses in Nonschizophrenic Subjects

\begin{tabular}{llc}
\hline Diagnosis & $\begin{array}{c}\text { Nonschizophrenic } \\
\text { Smoker } \\
(\boldsymbol{n}=\mathbf{1 0 )}\end{array}$ & $\begin{array}{c}\text { Nonschizophrenic } \\
\text { Nonsmoker } \\
(\boldsymbol{n}=\mathbf{1 1})\end{array}$ \\
\hline Current dysthymia & $1^{a, c, g}$ & 0 \\
Current panic disorder & $1^{a, g, i}$ & 0 \\
Current simple phobia & $2^{a, f, g}$ & 0 \\
Current agoraphobia & $1^{a, b, g}$ & 0 \\
Past obsessive-compulsive disorder & $1^{b}$ & $1^{b}$ \\
Past bipolar disorder & $1^{a, e, g}$ & 0 \\
Past major depression & $3^{a, d, g, h}$ & $2^{g, h}$ \\
Past substance abuse/dependence & $6^{a, b, c, d, f, f, g, i}$ & $4^{a, b}$ \\
Past alcohol abuse/dependence & $5^{b, c, d, e, f, i, g}$ & $1^{g}$ \\
None & 2 & 9 \\
\hline
\end{tabular}

Comorbid diagnoses:

a alcohol abuse/dependence.

${ }^{b}$ major depression.

${ }^{c}$ panic disorder.

${ }^{d}$ agoraphobia without panic disorder.

${ }^{e}$ simple phobia.

${ }^{\text {bipolar disorder. }}$

${ }^{g}$ substance abuse/dependence.

${ }^{h}$ obsessive-compulsive disorder.

${ }^{i}$ dysthymia. 
Exclusion criteria included current or past psychoses or a family history of schizophrenia. Because persons with psychiatric diagnoses are more likely to be smokers (Dalack and Glassman 1992; Glassman 1993), the smoking nonschizophrenic subject group had more subjects with current or past psychiatric diagnoses (Table 1). The nonschizophrenic subjects with current or past psychiatric diagnoses were not different from the nonschizophrenic subjects without psychiatric diagnoses in urinary bombesin-like peptide levels. One nonschizophrenic subject was taking $150 \mathrm{mg}$ of nortriptyline for migraine headaches; another was taking $75 \mathrm{mg}$ of amitriptyline for migraine headaches. Otherwise, no other nonschizophrenic subjects were taking psychotropic medications. After complete description of the study to the subjects, written informed consent was obtained.

Subjects were interviewed to determine any major respiratory symptoms (persistent cough, dyspnea), past lung diseases, second-hand smoke exposure, other environmental insults that contribute to lung disease, and family history of lung disease. Expired air content of carbon monoxide, a reflection of recent exposure to cigarette smoke that correlates with levels of carboxyhemoglobin (Jarvis et al. 1980), was measured with a portable carbon monoxide analyzer (Ecolyzer; Analysis Automation, Ltd.).

\section{URINE SAMPLE COLLECTION}

Urine samples were collected from schizophrenic patients and nonschizophrenic subjects. The samples were divided into three $15-\mathrm{ml}$ aliquots, one for creatinine determination, the second for cotinine analysis, and the third for bombesin-like peptide analysis; samples were then immediately centrifuged for 10 minutes to remove cellular debris. The sample for bombesin-like peptide measurement was immediately preserved by the addition of glacial acetic acid to a final concentration of $2 \mathrm{~N}$ and stored at $-70^{\circ} \mathrm{C}$. In a preliminary study, samples with creatinine levels of $<60 \mathrm{mg} / \mathrm{ml}$ did not have detectable bombesin-like peptide levels. Thus, if samples had creatinine levels of $<60 \mathrm{mg} / \mathrm{ml}$, the sample was reobtained as a first morning sample. Twenty-four hours prior to assay, the 15-ml urine sample was thawed, and $500 \mu \mathrm{l}$ aliquots were vacuum dried in a Savant Speed Vac concentrator (Savant Instruments, Farmingdale, NY) and reconstituted to the original volume of $500 \mu \mathrm{l}$ of $1 \%$ BSA-borate buffer, provided in the commercially available radioimmunoassay kit (Incstar Corporation, Stillwater, MN).

\section{BOMBESIN-LIKE PEPTIDE IMMUNOASSAY}

Bombesin-like peptide levels were determined using a radioimmunoassay procedure (Incstar Corporation,
Stillwater, MN). The antibody was raised in rabbits to a synthetic peptide that is identical to the tetradecapeptide originally isolated from frog skin. Nine of the amino acids are identical to those of gastrin-releasing peptide, which is thought to be the mammalian form of bombesin. The antibody is $50 \%$ crossreactive to porcine gastrin-releasing peptide and does not crossreact with substance $P$, neurotensin, somatostatin, met-enkephalin, eledoisin, or litorin (Johnson et al. 1982). Samples were analyzed in duplicate. The synthetic peptide was used to construct a standard curve. All subjects had levels above the minimal detectable amount $(40 \mathrm{pg} / \mathrm{ml})$. Levels were expressed as $\mathrm{pg} / \mathrm{mg}$ creatinine.

\section{STATISTICAL ANALYSIS}

To determine if smoking status or the diagnosis of schizophrenia influenced bombesin-like peptide levels, a two-way analysis of variance (ANOVA) was performed followed by specific contrasts between groups (Snedecor and Cochran 1989). Two-way ANOVAs for continuous variables and Chi squares for categorical or dichotomous variables were computed to test for significant differences between groups on demographics, major respiratory symptoms (persistent cough, dyspnea), past lung diseases, second-hand smoke exposure, other environmental insults that contribute to lung disease, family history of lung disease, and expired air content of carbon monoxide. Any variable for which the groups differed was then tested with an ANOVA for categorical variables or a Pearson correlation coefficient for continuous variables for the possibility of a relationship with the bombesin-like peptide level. Within the schizophrenic group, the relationship between antipsychotic medication type (typical, atypical, or none) and bombesin-like peptide level was tested by ANOVA.

Table 2. Comparison of Bombesin/Creatinine Levels in the Subject Groups ${ }^{a}$

\begin{tabular}{lccc}
\hline Subject Groups & F & df & $p$ Value \\
\hline Overall for all groups & 3.94 & 3,38 & 0.02 \\
Main effects: & & & \\
$\quad$ Schizophrenia diagnosis & 6.09 & 1,38 & 0.02 \\
$\quad$ Smoking status & 4.73 & 1,38 & 0.04 \\
$\quad$ 2-way interaction & 1.23 & 1,38 & 0.28 \\
Specific contrasts: & & & \\
$\quad$ Smoking vs. nonsmoking & 0.57 & 1,38 & 0.46 \\
$\quad$ Schizophrenic & 5.39 & 1,38 & 0.04 \\
$\quad$ Nonschizophrenic & 6.10 & 1,38 & 0.02 \\
Schizophrenic vs. nonschizophrenic & & \\
$\quad$ Smoking & 0.97 & 1,38 & 0.33 \\
$\quad$ Nonsmoking & & & \\
\hline
\end{tabular}

${ }^{a}$ Analysis of variance and specific contrasts, as described in Snedecor and Cochran (1989). 


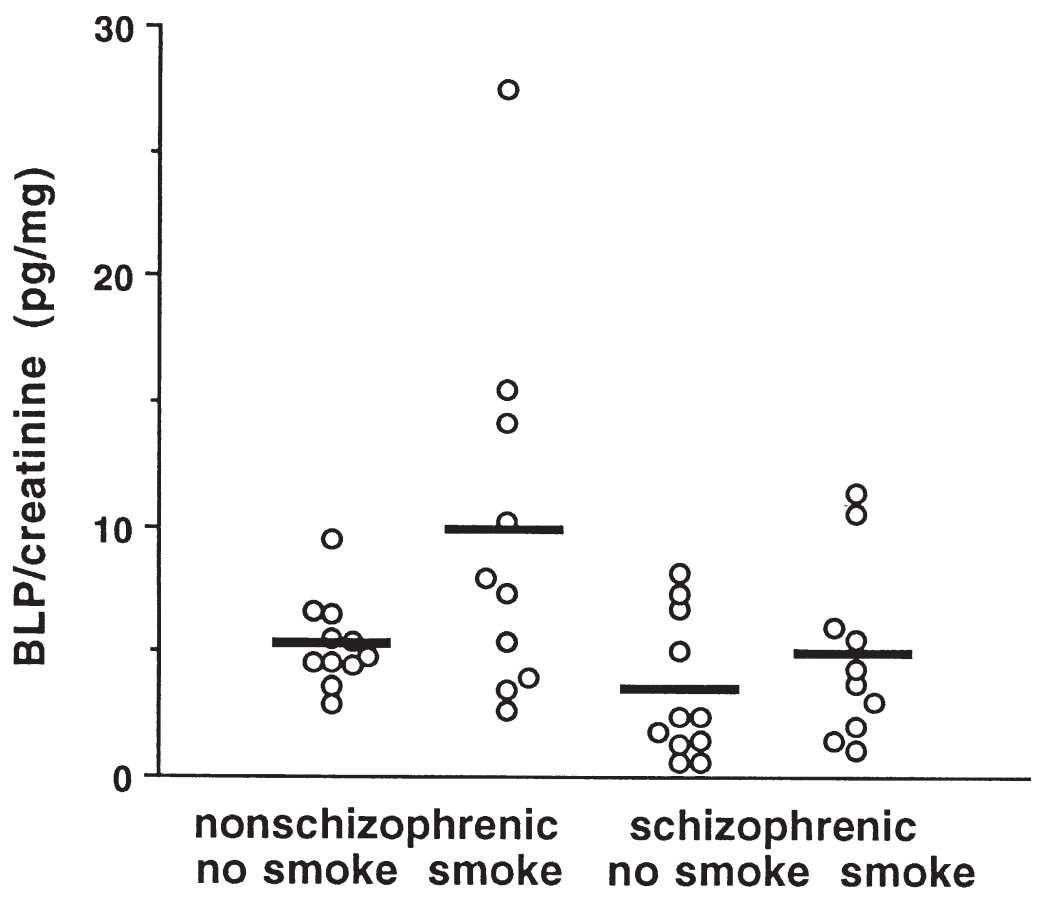

RESULTS

The two-way ANOVA showed significant effects of both smoking and the diagnosis of schizophrenia on bombesin-like peptide (Table 2). Significant specific contrasts between groups showed that the smoking, nonschizophrenic group had bombesin-like peptide levels that were higher than the nonsmoking, nonschizophrenic group. The smoking nonschizophrenic group also had higher bombesin-like peptide levels than the smoking schizophrenic group. The smoking schizophrenic group had levels that were not significantly different from either nonsmoking groups. Thus, schizophrenic patients have lower bombesin-like peptide levels, independent of smoking status (Figure 1).

The matching of subjects for pack-years and age precluded close matching in other demographic variables. Thus, the schizophrenic patients and the nonschizophrenic subjects differed with respect to education level, gender, marital status, exposure to secondary smoke in the home, past history of asthma, and past history of pneumonia (Table 3). However, two-way analysis of variances and Pearson correlation coefficients revealed no relationship of any of these variables to bombesin-like peptide levels (Table 4). There were no differences in the bombesin-like peptide levels of schizophrenic patients on atypical or typical neuroleptics (smoking: $\mathrm{F}=1.26$, $\mathrm{df}=1,7, p=$ ns; nonsmoking: $\mathrm{F}=0.35, \mathrm{df}=1,8, p=\mathrm{ns})$. The intensity of very recent exposure to nicotine, as measured by cotinine levels, did not significantly correlate with bombesin-like peptide levels.
Figure 1. Bombesin-like peptides levels standardized for creatinine levels (pg/mg) for nonschizophrenic smokers, schizophrenic smokers, nonschizophrenic nonsmokers, and schizophrenic nonsmokers. Mean (bar) and individual values are shown.
The increase in bombesin-like peptide levels in nonschizophrenic smokers, as compared to nonschizophrenic nonsmokers replicates a previous finding by Aguayo et al. (1992) in a much larger group of subjects. However, bombesin-like peptide levels in schizophrenic smokers were not increased when compared to schizophrenic nonsmokers. Bombesin-like peptide levels in schizophrenic smokers were also no different than bombesin-like peptide levels in nonschizophrenic nonsmokers. In addition, schizophrenic patients had lower bombesin-like peptide levels independent of smoking effects. These data suggest that neuroendocrine cell proliferation and potential tumor growth in schizophrenic patients may be decreased.

Bombesin-like peptide is found in human small cell lung cancer and in antral carcinomas (Kane et al. 1991; Zucker et al. 1989). Bombesin-like peptide is also found in noncancerous pulmonary and gastrointestinal cells (Scheurman et al. 1992; Scheubert and Makhlouf 1992). This peptide is secreted in bronchial fluid, where bronchial lavage levels correlate with urinary levels (Aguayo et al.1992). However, urinary bombesin likely has sources in addition to pulmonary cells. Bombesinlike peptide is also found in cerebrospinal fluid (CSF), where it presumably comes from the neuroendocrine cells that form the catecholamine-producing neurons of the brain (Lynn et al. 1996). Bombesin-like peptide levels in CSF of schizophrenic psychiatric patients have been shown to be lower than bombesin-like peptide levels in nonschizophrenic psychiatric patients in two 
Table 3. Comparison of Schizophrenic and Nonschizophrenic Groups of Possible Confounding Factors

\begin{tabular}{|c|c|c|c|}
\hline & Schizophrenic & Nonschizophrenic & Significance \\
\hline \multicolumn{4}{|l|}{ Pack-years, mean $\pm S D$} \\
\hline Smokers & $21.00 \pm 11.29$ & $20.90 \pm 13.75$ & \\
\hline Nonsmokers & $2.73 \pm 5.41$ & $3.41 \pm 7.51$ & \\
\hline Schizophrenia diagnosis & & & $\mathrm{F}[1,38]=0.01 ; p<.92$ \\
\hline Smoking status & & & $\mathrm{F}[1,38]=34.76 ; p<.001$ \\
\hline \multicolumn{4}{|l|}{ Carbon Monoxide (ppm), mean \pm SD } \\
\hline Smokers & $36.67 \pm 12.26$ & $20.10 \pm 13.19$ & \\
\hline Nonsmokers & $4.09 \pm 0.83$ & $3.82 \pm 0.60$ & \\
\hline Schizophrenia diagnosis & & & $\mathrm{F}[1,37]=9.61 ; p<.004$ \\
\hline Smoking status & & & $\mathrm{F}[1,37]=80.93 ; p<.001$ \\
\hline \multicolumn{4}{|l|}{ Cotinine $(\mathrm{ng} / \mathrm{ml})$, mean $\pm \mathrm{SD}$} \\
\hline Smokers & $229.69 \pm 168.48$ & $169.51 \pm 128.57$ & \\
\hline Nonsmokers & $0.27 \pm 0.24$ & $0.16 \pm 0.27$ & \\
\hline Schizophrenia diagnosis & & & $\mathrm{F}[1,37]=0.91 ; p<.35$ \\
\hline Smoking status & & & $\mathrm{F}[1,37]=39.84 ; p<.001$ \\
\hline Education (years), mean \pm SD & $13.00 \pm 2.17$ & $16.91 \pm 2.93$ & $\mathrm{~F}[1,40]=24.09 ; p<.001$ \\
\hline \multicolumn{3}{|l|}{ Marital status, $n(\%)$} & $\chi^{2}[3]=8.24 ; p<.04$ \\
\hline Single & $13(62)$ & $4(19)$ & \\
\hline Married & $3(14)$ & $8(38)$ & \\
\hline Divorced & $2(10)$ & $3(14)$ & \\
\hline Divorced, remarried & $3(14)$ & $6(29)$ & \\
\hline \multicolumn{3}{|l|}{ Gender, $n(\%)$} & $\chi^{2}[1]=6.11 ; p<.01$ \\
\hline Male & $14(67)$ & $6(29)$ & \\
\hline Female & $7(33)$ & $15(71)$ & \\
\hline \multicolumn{3}{|l|}{ Ethnicity, $n(\%)$} & $\chi^{2}[2]=1.23 ; p<.54$ \\
\hline Caucasian & $18(85)$ & $19(90)$ & \\
\hline African American & $1(5)$ & $2(10)$ & \\
\hline Hispanic & $2(10)$ & $0(0)$ & \\
\hline \multicolumn{3}{|l|}{ Cough A.M., $n(\%)$} & $\chi^{2}[1]=1.03 ; p<.60$ \\
\hline Yes & $5(24)$ & $1(5)$ & \\
\hline No & $16(76)$ & $20(95)$ & \\
\hline \multicolumn{3}{|l|}{ Cough P.M., $n(\%)$} & $\chi^{2}[1]=0.78 ; p<.38$ \\
\hline Yes & $4(19)$ & $2(10)$ & \\
\hline \multirow{2}{*}{\multicolumn{3}{|c|}{ Past history asthma, $n(\%)$}} & \\
\hline & & & $\chi^{2}[1]=5.56 ; p<.02$ \\
\hline Yes & $1(5)$ & $7(33)$ & \\
\hline No & $20(95)$ & $14(67)$ & \\
\hline \multicolumn{3}{|l|}{ Past history bronchitis, $n(\%)$} & $\chi^{2}[1]=0.62 ; p<.43$ \\
\hline Yes & $3(14)$ & $5(24)$ & \\
\hline No & $18(86)$ & $16(76)$ & \\
\hline \multicolumn{3}{|l|}{ Past history emphysema, $n(\%)$} & $\chi^{2}[1]=1.02 ; p<.31$ \\
\hline Yes & $1(5)$ & $0(0)$ & \\
\hline No & $20(95)$ & $21(0)$ & \\
\hline \multicolumn{3}{|l|}{ Past hisory pneumonia, $n(\%)$} & $\chi^{2}[1]=4.29 ; p<.04$ \\
\hline Yes & $1(5)$ & $6(29)$ & \\
\hline No & $20(95)$ & $15(71)$ & \\
\hline \multicolumn{3}{|l|}{ Family history emphysema, $n(\%)$} & $\chi^{2}[2]=2.83 ; p<.24$ \\
\hline No & $16(76)$ & $17(81)$ & \\
\hline $1^{\circ}$ & $1(5)$ & $3(14)$ & \\
\hline $2^{\circ}$ & $4(19)$ & $1(5)$ & \\
\hline \multicolumn{3}{|l|}{ Family history lung cancer, $n(\%)$} & $\chi^{2}[3]=2.03 ; p<.56$ \\
\hline No & $18(86)$ & $17(81)$ & \\
\hline $1^{\circ}$ & $1(5)$ & $1(5)$ & \\
\hline $2^{\circ}$ & $1(5)$ & $3(14)$ & \\
\hline $3^{\circ}$ & $1(5)$ & $0(0)$ & \\
\hline \multicolumn{3}{|l|}{ Secondary smoke at home, $n(\%)$} & $\chi^{2}[1]=4.72 ; p<.02$ \\
\hline Yes & $8(38)$ & $19(90)$ & \\
\hline No & $13(62)$ & $2(10)$ & \\
\hline
\end{tabular}


Table 3. Continued

\begin{tabular}{lccc}
\hline & Schizophrenic & Nonschizophrenic & Significance \\
\hline Secondary smoke as a child, $n(\%)$ & & & $\chi^{2}[1]=0.00 ; p<1.0$ \\
$\quad$ Yes & $15(71)$ & $6(71)$ & $\chi^{2}[1]=1.02 ; p<.31$ \\
$\quad$ No & $6(29)$ & $0(0)$ & \\
Secondary smoke at work, $n(\%)$ & $1(5)$ & $21(100)$ & $\chi^{2}[1]=1.02 ; p<.31$ \\
$\quad$ Yes & $20(95)$ & $0(0)$ & \\
No & $1(5)$ & $21(100)$ & $\chi^{2}[1]=0.36 ; p<.55$ \\
Exposure to asbestos, $n(\%)$ & $20(95)$ & $1(5)$ & $20(95)$ \\
$\quad$ Yes & $2(10)$ & $19(90)$ & \\
No & & \\
$\quad$ Yes & & \\
No & & \\
\hline
\end{tabular}

studies (Gerner and Yamada 1982; Gerner et al. 1985), although nicotine exposure was not controlled in either study. In these same studies, other CSF peptides, including cholycystokinin and somatostatin, did not show decreased levels in schizophrenic patients. Thus, the biological differences found in schizophrenic patients' pulmonary neuroendocrine cells in the present study may be more generalized.

There are several possible explanations for the differences in the schizophrenic patients' bombesin-like peptide response to smoking. Despite the similar smoking histories of the two groups, the schizophrenic patients actually have significantly higher expired carbon monoxide levels; thus a decreased exposure to nicotine is not a likely mechanism. Neuroleptic treatment is another difference between the groups, which could account for the variance in the bombesin-like peptide levels. Neuroleptics might protect schizophrenic patients from chronic effects of cigarette smoke on neuroendocrine cell hyperplasia or may have a generalized effect of lowering bombesin-like peptide. However, one of the previous studies of CSF bombesin-like peptide found low levels in schizophrenic patients unmedicated for 14 to 77 days (Gerner et al. 1985). Of course, it is possible that such a brief off-drug period might not be sufficient to counteract the chronic effects of neuroleptic exposure. However, comparison of the schizophrenic patients on typical neuroleptics, with the schizophrenic patients on atypical neuroleptics or no medication, demonstrates no differences in the smokers or the nonsmokers on the level of bombesin-like peptide $(\mathrm{F}=1.19$, df $=2,19, p=.33$ ).

Because bombesin-like peptide is produced by pulmonary neuroendocrine cell proliferation, and nicotine stimulates growth of these neuroendocrine cells in vitro, a nicotinic receptor difference between groups may explain the lower levels of bombesin-like peptide in schizophrenic patients. The nicotine stimulation of growth of neuroendocrine cells as well as small cell lung cancer cells in vitro is antagonized by $\alpha$-bungaro- toxin, implicating a mechanism involving the $\alpha 7$ nicotinic cholinergic receptor (Chan and Quik 1993; Codignola et al. 1994; Quik et al. 1994). The $\alpha 7$ receptor is also found on pulmonary neuroendocrine cells in vivo (Schuller 1989; Schuller et al. 1990). Thus, a third possible mechanism for the difference in bombesin-like peptide levels between groups is an altered response of the $\alpha 7$ receptor on pulmonary neuroendocrine cells in the schizophrenic patients.

The expression of the $\alpha 7$ nicotinic receptor in lung tissue from schizophrenic patients has not been studied, but $\alpha 7$ expression is decreased in schizophrenic patients' hippocampi (Freedman et al. 1995). Furthermore, a genetic linkage study has shown inheritance of one of the psychophysiological deficits associated with schizophrenia at the chromosome 15q13-14 locus of the $\alpha 7$ nicotinic receptor gene (Freedman et al. 1997). Several of the psychophysiological deficits in schizophrenia are normalized by nicotine, including the P50 deficit that is linked to the locus of the $\alpha 7$ nicotinic receptor (Adler et al. 1992; Adler et al. 1993) and one of the smooth pursuit eye movement abnormalities, which also shows evidence for linkage at this site (Olincy et al. 1997b; Olincy et al. 1998). The analysis of variance in the present study shows no interaction between the main effects of nicotine and schizophrenia on bombesin-like peptide levels. Thus, it is likely that the proliferation of

Table 4. Relationship of Variables Different Between Schizophrenic and Nonschizophrenic Groups to Bombesin/ Creatinine Levels

\begin{tabular}{lccc}
\hline & F or $\mathbf{~}^{2}$ & df & $\boldsymbol{p}$ Value \\
\hline Gender & $\mathrm{r}^{2}=0.28$ & 42 & 0.07 \\
Marital status & $\mathrm{r}^{2}=0.09$ & 42 & 0.56 \\
Education & $\mathrm{F}=0.78$ & 12,25 & 0.67 \\
Secondary smoke in the home & $\mathrm{r}^{2}=-0.07$ & 42 & 0.66 \\
Past history asthma & $\mathrm{r}^{2}=-0.10$ & 42 & 0.55 \\
Past history pneumonia & $\mathrm{r}^{2}=-0.06$ & 42 & 0.07 \\
\hline
\end{tabular}


neuroendocrine tissue is also responsive to nicotine in schizophrenic patients. However, the diminished bombesin-like peptide levels in schizophrenic patients, regardless of smoking status, may, nonetheless, reflect an $\alpha 7$ receptor deficit. If $\alpha 7$ receptor expression is diminished, but not absent, as suggested by the study of $\alpha$-bungarotoxin binding in the hippocampus (Freedman et al. 1995), then a partial response would be expected. The diminished receptor expression may be the result of the autosomal dominant inheritance of a genetic abnormality, which leaves the proband with only one normal allele (Freedman et al. 1997). As a result, nonsmoking schizophrenic patients may have a diminished response to acetylcholine or whatever endogenous ligands control normal neuroendocrine cell growth, and smoking schizophrenic patients may additionally have a diminished response to exogenous nicotine. A common nicotinic receptor deficit could, thus, be responsible for both decreased rates of lung cancer and the inheritance of psychophysiological abnormalities in schizophrenia.

\section{REFERENCES}

Adler LE, Hoffer LJ, Griffith J, Waldo M, Freedman R (1992): Normalization by nicotine of deficient auditory sensory gating in the relatives of schizophrenics. Biol Psychiat 32:607-616

Adler LE, Hoffer LJ, Wiser A, Freedman R (1993): Normalization of auditory physiology by cigarette smoking in schizophrenic patients. Am J Psychiat 150:1856-1861

Aguayo SM, King TE, Waldron JA, Sherritt KM, Kane MA, Miller YE (1990): Increased pulmonary neuroendocrine cells with bombesin-like immunoreactivity in adult patients with eosinophillic granuloma. J Clin Ivest 86: 838-844

Aguayo SM, King TE, Kane MA, Sherritt KM, Silvers W, Nett LM, Petty TL, Miller YE (1992): Urinary levels of bombesin-like peptides in asymptomatic cigarette smokers: A potential risk marker for smoking-related diseases. Cancer Res 52:2727s-2731s

Aguayo SM (1993): Pulmonary neuroendocrine cells in tobacco-related lung disorders. Anat Rec 236:122-127

American Psychiatric Association (1987): Diagnostic and Statistical Manual of Mental Disorders, 3rd ed., revised. Washington, DC, American Psychiatric Association

Baldwin JA (1979): Schizophrenia and physical disease. Psychol Med 9:611-618

Chan J, Quik M (1993): A role for the nicotinic $\alpha$-bungarotoxin receptor in nurite outgrowth in PC12 cells. Neuroscience 56:441-451

Codignola A, Tarroni P, Cattaneo MG, Vicentini LM, Clementi F, Sher E (1994): Serotonin release and cell proliferation are under the control of $\alpha$-bungarotoxin-sensitive nicotinic receptors in small-cell lung carcinoma cell lines. FEBS Lett 342:286-290
Craig TJ, Lin SP (1981): Cancer and mental illness. Compr Psychiat 22:404-410

Cuittita F, Carney DN, Mulshine J, Moody TW, Fedorko J, Fishler A, Minna JD (1985): Bombesin-like peptides can function as autocrine growth factors in human small cell lung cancer. Nature 316:823-826

Dalack GW, Glassman AH (1992): A clinical approach to help psychiatric patients with smoking cessation. Psychiatr Q 63:27-39

de Leon J, Dadvand M, Canuso C, White AO, Stanilla JK, Simpson GM (1995): Schizophrenia and smoking: An epidemiological survey in a state hospital. Am J Psychiat 152:453-455

Endicott J, Andreasen N, Spitzer RL (1978): Family HistoryResearch Diagnostic Criteria, 3rd ed. New York, Research Assessment and Training Unit, New York State Psychiatric Institute

Freedman R, Hall M, Adler LE, Leonard S (1995): Evidence in postmortem brain tissue for deceased numbers of hippocampal nicotinic receptors in schizophrenia. Biol Psychiat 38:22-33

Freedman R, Coon H, Myles-Worsley M, Orr-Urtreger A, Olincy A, Davis A, Polymeropoulos M, Holik J, Hopkins J, Hoff M, Rosenthal J, Waldo MC, Reimherr F, Wender P, Yaw J, Young D, Breese C, Adams C, Patterson D, Adler LE, Kruglyak L, Leonard S, Byerley W (1997): Linkage of a neurophysiological deficit in schizophrenia to a chromosome 15 locus. Proc Natl Acad Sci USA 94:587-592

Glassman AH (1993): Cigarette smoking: implication for psychiatric illness. Am J Psychiat 150:546-553

Gerner RH, Yamada T (1982): Altered neuropeptide concentration in cerebral spinal fluid of psychiatric patients. Brain Res 238:298-302

Gerner RH, Van Kammen DP, Ninan PT (1985): Cerebrospinal fluid cholecystokinin, bombesin, and somatostatin in schizophrenia and normals. Prog Neuropsychopharmacol Biol Psychiat 9:73-82

Gulbinat W, Dupont A, Jablensky A, Jensen OM, Marsella A, Nakane Y, Sartorius N (1992): Cancer incidence of schizophrenic patients results of record linkage studies in three countries. Br J Psychiat 161:75-85

Hecht SS, Hoffman D (1988): Tobacco-specific nitrosamines, and important group of carcinogens in tobacco and tobacco smoke. Carcinogenesis 9:875-884

Jarvis MJ, Russell MAH, Saloojee Y (1980): Expired air carbon monoxide: A simple breath test for tobacco smoke intake. BMJ 288:484-485

Johnson CE, Lock JE, Elde RP, Thompson TR (1982): Pulmonary neuroendocrine cells in hyaline membrane disease and bronchopulmonary dysplasia. Pediatr Res 16:446-454

Lohr JB, Flynn K (1992): Smoking and schizophrenia. Schizophr Res 8:93-102

Kane MA, Aguayo SM, Portanova LB, Ross SE, Holley M, Kelley K, Miller YE (1991): Isolation of the bombesin/gastrin-releasing peptide receptor from human small cell lung carcinoma NCI-H354 cells. J Biol Chem 266:9486-9493

Lynn RB, Hyde TM, Cooperman RR, Miselis RR (1996): Distribution of bombesin-like immunoreactivity in the 
nucleus of the solitary tract and dorsal motor nucleus of the rat and human: Colocalization with tyrosine hydroxylase. J Comp Neurol 369:552-570

McEvoy JP, Freudenreich O, Levin ED, Rose JE (1995): Haloperidol increases smoking in patients with schizophrenia. Psychopharmacology 119:124-126

Masterson E, O'Shea B (1984): Smoking and malignancy in schizophrenia. Br J Psychiatr 145:429-432

Minna JD (1993): The molecular biology of lung cancer pathogenesis. Chest 103:445s-456s

Olincy A, Young DA, Freedman R (1997a): Increased levels of the nicotine metabolite cotinine in schizophrenic smokers compared to other smokers. Biol Psychiat 42:1-5

Olincy A, Ross RG, Leonard S, Freedman R (1997b): Preliminary linkage of eye movement abnormalities in schizophrenia. Soc Biolog Psychiat 41:84S

Olincy A, Ross RG, Young DA, Roath M, Freedman R (1998): Improvement in smooth pursuit eye movements after cigarette smoking in schizophrenic patients. Neuropsychopharmacology 18:175-185

Quik M, Chan J, Patrick J (1994): $\alpha$-bungarotoxin blocks the nicotinic receptor mediated increase in cell number in a neuroendocrine cell line. Brain Res 655:161-167

Rassidakis NC, Kelepouris M, Goulis R, Karaiossefidis K (1971): Malignant neoplasm as a cause of death among psychiatric patients. Internat Ment Hlth Res Newslett 14:1
Rice D (1979): No lung cancer in schizophrenics? Br J Psychiat 134:128

Scheubert ML, Makhlouf GM (1992): Neural, hormonal, and paracrine regulation of gastrin and acid secretion. Yale J Biol Med 65:553-560

Scheurman DW, Adrioaensen D, Timmermans JP, DeGroodtLasseel MH (1992): Comparative histological overview of the chemical coding of the pulmonary neuroepithelial endocrine system in health and disease. Eur J Morphol 30:101-112

Schuller HM (1989): Cell type specific, receptor-mediated modulation of growth kinetics in human lung cancer cell lines by nicotine and tobacco-related nitrosamines. Biochem Pharmacol 38:3439-3442

Schuller HM, Nylen E, Park P, Becker KL (1990): Nicotine, acetylcholine, and bombesin are trophic growth factors in neuroendocrin cell lines derived from experimental hamster lung tumors. Life Sci 47:571-578

Snedecor GW, Cochran WG (1989): Statistical Methods. Ames, Iowa, Iowa State University Press

Spitzer RL, Williams JBW, Gibbon M, First MB (1990): Structured Clinical Interview for DSM-III-R-Nonpatient Edition (SCID-NP, Version 1.0). Washington, DC, American Psychiatric Press

Zucker KA, Longo WE, Modlin IM, Bilchik AJ, Adrian TE (1989): Malignant diathesis from jejunal-ilieal carcinoids. Am J Gastroenterol 84:182-186 